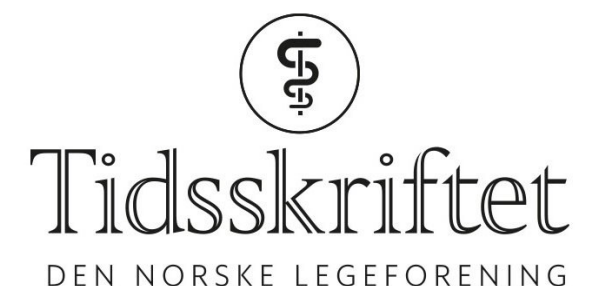

DEN NORSKE LEGEFORENING

\title{
Nyanser av variasjon
}

MEDISIN OG TALL

\section{ARE HUGO PRIPP}

Are Hugo Pripp (f. 1971) er forsker og biostatistiker ved Oslo senter for biostatistikk og epidemiologi, Forskningsstøtteavdelingen, Oslo universitetssykehus, og professor II ved Fakultet for helsefag, Høgskolen i Oslo og Akershus. Forfatter har fylt ut ICMJE-skjemaet og oppgir ingen interessekonflikter.

Målinger fra samme individ kan variere, målinger fra forskjellige individer kan variere, og gjennomsnittsmålinger fra forskjellige utvalg av individer kan variere. Alt dette er ulike nyanser av variasjon, og forståelse av dem er viktig for riktig bruk av statistikk i medisin.

Alt fra vurderinger av diagnose og prognose til en enkelt pasient, til hvorvidt det er effekt av intervensjonen i en klinisk studie, er i stor grad avhengig av observasjoner, målinger og tall. I medisinsk forskning blir disse ofte registrert som variabler i et datasett. Variabel stammer fra det latinske ordet variabilis som betyr noe som er «skiftende, foranderlig, som endrer seg» (1). Hvis noe derimot ikke kan endre seg, er det en konstant. Jeg vil hevde at i medisin og statistikk er det mange flere variabler enn konstanter.

\section{Variasjon i et utvalg}

Vi beskriver variasjon med såkalte spredningsmål (tab 1). Et spredningsmål kan være null eller større. Hvis det ikke er variasjon blant observasjonene eller målingene, er spredningsmålet null. Jo større variasjon, desto høyere verdi for spredningsmålet.

\section{Tabell 1}

Variasjonen til en målemetode, observasjoner i et utvalg eller et estimat fra et utvalg har ulike statistiske mål for variasjon

\begin{tabular}{|ll|}
\hline Nyanser av variasjon & Statistiske mål for variasjon \\
\hline Hvor nøyaktig er målingen? $\rightarrow$ & Standardfeilen til målingen \\
\hline Hvor stor er spredningen i utvalget? $\rightarrow$ & Standardavviket \\
\hline Hvor presist er estimatet fra utvalget? $\rightarrow$ & Standardfeilen \\
\hline
\end{tabular}

Standardavvik, varians og variasjonsbredde er eksempler på spredningsmål som er mye brukt. Standardavviket uttrykker verdienes gjennomsnittlige avstand fra gjennomsnittet (og er statistisk-matematisk kvadratroten av variansen). Hvis verdiene i et datasett varierer lite fra gjennomsnittet, blir standardavviket lavt. En statistisk tommelfingerregel er at ett, to eller tre standardavvik i begge retninger fra gjennomsnittet vil omfatte henholdsvis 68, 95 eller $99 \%$ av alle verdiene i datasettet. Ved bare å oppgi gjennomsnittet og 
standardavviket beskriver vi mye informasjon om hele datasettet, spesielt hvis tallene er noenlunde normalfordelt.

Et annet mye brukt spredningsmål er variasjonsbredden (range). Variasjonsbredden er ofte angitt ved å oppgi minimums- og maksimumsverdiene, men er statistisk sett egentlig differansen mellom største og minste observerte verdi.

Konseptuelt er mål for variasjon ikke avgrenset til spredning mellom forskjellige individer eller prøver i et utvalg. Begreper som reliabilitet, måleusikkerhet, konfidensintervall og statistisk signifikanstest er nært relatert til statistisk variasjon.

\section{Måleusikkerhet}

Gjentatte målinger fra samme individ ved de samme betingelsene kan variere uten at individet endrer seg reelt eller medisinsk fra måling til måling. Denne variasjonen er relatert til repeterbarheten eller reproduserbarheten.

Hvis målingen er gjentatt under mest mulig like betingelser, er det repeterbarhet. Hvis målingen utføres under varierende betingelser, for eksempel ved ulike laboratorier, av ulike personer eller med forskjellig utstyr, er det reproduserbarhet. Variasjonen til slike repeterte (eller reproduserte) målinger uttrykker reliabiliteten til en test eller måling, og er dermed et uttrykk for måleusikkerheten eller målingens nøyaktighet.

Det finnes flere mål for denne nyansen av variasjon. Standardfeilen til målingen (standard error of measurement) er egentlig standardavviket til slike repeterte (eller reproduserte) verdier. Ved å beregne standardfeilen til målingen kan vi utlede et statistisk uttrykk for minste påvisbare endring. Dette er differansen mellom to målinger på samme individ som sannsynligvis ikke bare skyldes måleusikkerhet. Denne differansen er også kalt repeterbarhetskoeffisienten (2).

\section{Variasjon mellom utvalg}

Gjennomsnittsverdier, koeffisienter fra regresjonsmodeller eller estimater av risiko er typiske eksempler på statistiske estimater fra utvalg. Presisjonen til slike estimater uttrykker en annen nyanse av variasjon som er relatert til viktige statistiske begreper som pverdier, signifikanstester og konfidensintervaller.

La oss tenke oss at vi beregnet gjennomsnittsverdien fra forskjellige uavhengige utvalg med samme antall individer. Hver enkelt gjennomsnittsverdi ble registrert i et nytt datasett. Standardavviket til disse enkelte gjennomsnittsverdiene ville bli det vi ofte kaller for standardfeilen til gjennomsnittet (standard error of the mean). Altså, standardfeilen til gjennomsnittet er egentlig et standardavvik, men da for gjennomsnittsverdiene og ikke de enkelte målingene i utvalget.

Vi kan bruke standardfeilen til estimatet for å beregne konfidensintervallet. En ikke uvanlig misforståelse er at nivået til konfidensintervallet - for eksempel 95\% - angir

sannsynligheten for at populasjonens sanne verdi ligger innenfor det estimerte intervallet (3). En mer korrekt definisjon er at konfidensintervallet er et estimert intervall av en populasjonsparameter beregnet fra de observerte dataene. Hvis vi estimerte $95 \%$ konfidensintervaller i et uendelig antall uavhengige eksperimenter, ville $95 \%$ av disse intervallene inneholde den sanne populasjonsverdien.

Standardfeil og konfidensintervall gir oss viktig statistisk informasjon om presisjonen til estimater fra utvalg, men er ikke et mål for spredningen til enkeltmålingene. Utvalg med mye spredning og dermed et høyt standardavvik kan gi estimater med en liten standardfeil og et smalt konfidensintervall. For å få et smalt konfidensintervall (og dermed ofte en tilhørende lav p-verdi), gjelder det å ha mange observasjoner i utvalget. Jo flere observasjoner, desto lavere standardfeil og smalere konfidensintervall. Derimot blir standardavviket ikke påvirket av antall observasjoner i utvalget. 
De mange nyansene av spredning og variasjon til data er essensielt i statistikk. Disse gir viktig informasjon om måleusikkerheten til en målemetode, spredningen i et utvalg eller presisjonen til et estimat.

LITTERATUR:

1. Bokmålsordboka. http://ordbok.uib.no/perl/ordbok.cgi?OPP-

variabel\&ant_bokmaal=5\&ant_nynorsk=5\&bokmaal=+\&ordbokbokmaal (5.9. 2017).

2. Bartlett JW, Frost C. Reliability, repeatability and reproducibility: analysis of measurement errors in continuous variables. Ultrasound Obstet Gynecol 2008; 31: 466 - 75. [PubMed][CrossRef]

3. Hoekstra R, Morey RD, Rouder JN et al. Robust misinterpretation of confidence intervals. Psychon Bull Rev 2014; 21: 1157 - 64. [PubMed][CrossRef]

Publisert: 8. januar 2018. Tidsskr Nor Legeforen. DOI:10.4045/tidsskr.17.076o

(C) Tidsskrift for Den norske legeforening 2020. Lastet ned fra tidsskriftet.no 